\title{
O Profissional da Saúde e a Síndrome de Burnout: Reflexões para a Humanização
}

\author{
Zanatta, Aline Bedin; Lucca, Sergio Roberto de \\ Universidade Estadual de Campinas- Unicamp — alinezanatta@yahoo.com.br
}

Introdução: ao se analisar o trabalho em saúde percebe-se que este suscita sentimentos muito fortes e contraditórios nos profissionais da saúde; como piedade, compaixão e amor; culpa e ansiedade; ódio e ressentimento contra os pacientes que fazem emergir esses sentimentos fortes; responsabilidade pelo sucesso do tratamento com o paciente, contato direto com a dor e a morte. Estas características podem induzir o profissional da saúde à um estresse profissional: a síndrome de Burnout que é um fenômeno psicossocial que surge como resposta aos estressores interpessoais crônicos presentes no trabalho. Objetivos: Refletir sobre as características do trabalho dos profissionais da saúde como causador de sofrimento mental e esgotamento profissional. Metodologia: Ensaio teórico reflexivo com revisão ampliada da literatura. Resultados: o Burnout é referido como uma síndrome multidimensional constituída por exaustão emocional, desumanização e reduzida realização pessoal no trabalho. um profissional que está Burnout, tende a criticar tudo e todos que o cercam, tem pouca energia para as diferentes solicitações de seu trabalho, desenvolve frieza e indiferença para com as necessidades e o sofrimento dos outros, tem sentimentos de decepção e frustração e comprometimento da autoestima. Assim, se considerarmos que o profissional da saúde tende a escolher esta área de atuação por uma vontade de cuidar, sentida às vezes enquanto vocação ou missão uma dimensão de cuidador que todos os profissionais de saúde têm é possível supor que, quando o trabalho em saúde toma configurações que o distanciam desta realidade, torna-se frustrante e insatisfatório, estressante, até adoecedor. Conclusões: Se tratando de cuidados de saúde, sempre teremos complexas inter-relações humanas entre quem presta e recebe o cuidado: "o corpo que sente do doente, corpo que sente do trabalhador", e que estas relações interagem constantemente e fazem parte da "arte" de cuidar, o que faz compreender que, antes do cuidado com o outro, vem à importância do cuidado de si. Além disso, na prática diária destes profissionais é orientado e muitas vezes cobrado para que tenham uma atitude humanizada com todos os pacientes, porém, a questão que fica é se os profissionais também estão sendo cuidados e se são tratados de maneira humanizada pelas instituições, serviços de saúde e estado para os quais prestam serviço, visto que se observam jornadas exaustivas, excesso de pacientes por profissional, e, consequentemente, acúmulo de sobrecarga e responsabilidade. uma medida profilática importante para evitar a insalubridade psicológica do trabalho em saúde seria a inclusão da dimensão psicológica ainda na formação dos estudantes da área da saúde, visando a sensibilização antecipada, além disso, deveria ser estimulada a organização de serviços de assistência psicológica e psiquiátrica aos alunos e profissionais da saúde em todas as instituições que prestam o cuidado.

Zanatta, Aline Bedin; Lucca, Sergio Roberto de. O Profissional da Saúde e a Síndrome de Burnout: Reflexões para a Humanização. In: Anais do Congresso Internacional de Humanidades \& Humanização em Saúde [= Blucher Medical Proceedings, num.2, vol.1]. São Paulo: Editora Blucher, 2014. ISSN 2357-7282 DOI 10.5151/medpro-cihhs-10443 